Columbia Law School

Scholarship Archive

1975

\title{
Assessing the Distributional Effects of Income Tax Revision: Some Lessons from Incidence Analysis
}

Michael J. Graetz

Columbia Law School, mgraet@law.columbia.edu

Follow this and additional works at: https://scholarship.law.columbia.edu/faculty_scholarship

Part of the Taxation-Federal Commons, and the Tax Law Commons

\section{Recommended Citation}

Michael J. Graetz, Assessing the Distributional Effects of Income Tax Revision: Some Lessons from Incidence Analysis, 4 J. LEGAL STUD. 351 (1975).

Available at: https://scholarship.law.columbia.edu/faculty_scholarship/2612

This Article is brought to you for free and open access by the Faculty Publications at Scholarship Archive. It has been accepted for inclusion in Faculty Scholarship by an authorized administrator of Scholarship Archive. For more information, please contact scholarshiparchive@law.columbia.edu, rwitt@law.columbia.edu. 


\title{
ASSESSING THE DISTRIBUTIONAL EFFECTS OF INCOME TAX REVISION: SOME LESSONS FROM INCIDENCE ANALYSIS
}

\author{
MICHAEL J. GRAETZ*
}

I

$\mathrm{N}$ recent years public attention to issues of tax equity has increased dramatically. The testimony in January 1969 of outgoing Secretary of the Treasury Joseph Barr that 154 individuals who had adjusted gross incomes of more than $\$ 200,000$ in 1966 paid no federal income tax intensified public awareness and concern about the equity of the tax system. Tax reform has remained a central issue of public policy.

At the same time, scholars working in the tax field have refined their methods of analyzing the impact on individuals and classes of individuals of tax laws and tax changes. Theoretical advances in two areas have been particularly important: analysis of tax incidence and shifting; ${ }^{1}$ and tax expenditure analysis. ${ }^{2}$ Curiously, however, these analytical techniques have not been combined to evaluate distributional consequences of changes in the personal income tax. Tax expenditure analysis treats income tax discrimination among various income-generating activities as the functional equivalent of a subsidy to the activity that receives relatively favorable treatment. Tax incidence analysis teaches that a tax (or a subsidy) on a particular activity will be borne, at least in part, by persons other than those engaging in the activity

* Associate Professor of Law, University of Virginia. The author would like to express his appreciation to Richard Bonnie, Jerry Mashaw, Warren Schwartz, and Emil Sunley for their helpful comments on an earlier draft of this article.

1 For a good collection of the literature concerning tax incidence, see Peter Mieszkowski, Tax Incidence Theory: The Effects of Taxes on the Distribution of Income, $9 \mathrm{~J}$. Econ. Lit. 1103 (1969). The literature is summarized and appraised in George F. Break, The Incidence and Economic Effects of Taxation, in Alan S. Blinder, et al., The Economics of Public Finance 119 (Brookings, 1974) [hereinafter cited as Break]. See also Horst Claus Recktenwald, Tax Incidence and Income Redistribution (Martha V. Stolper trans. 1971) [hereinafter cited as Recktenwald].

2 See Stanley S. Surrey, Tax Incentives as a Device for Implementing Government Policy: A Comparison with Direct Government Expenditures, 83 Harv. L. Rev. 705 (1970); Federal Income Tax Reform: The Varied Approaches Necessary to Replace Tax Expenditures With Direct Governmental Assistance, 84 Harv. L. Rev. 352 (1970); Pathways to Tax Reform: The Concept of Tax Expenditures (1973) [hereinafter cited as Pathways]. Compare Boris I. Bittker, Accounting for Federal "Tax Subsidies" in the National Budget, 22 Nat. Tax. J. 244 (1969). 
who are nominally subject to the tax. It would seem to follow that the impact of income tax discrimination among various types of income-producing activity would likewise extend to persons other than the nominal taxpayer. Nevertheless, estimates of the distributive effect of changes in the personal income tax law are typically based on the assumption that the person nominally affected by the change will bear its entire impact. In this article I will merge incidence and tax expenditure approaches to question this assumption.

\section{Tax Expenditure Analysis}

Tax expenditure analysis identifies a system of "tax expenditures" under which government financial assistance is carried out through special tax provisions rather than through direct government expenditures. It is argued that using the tax system rather than direct payments produces inefficiencies in the allocation of resources and inequities in the distribution of the tax burden because "[Tax Expenditures] are worth more to the High Income Taxpayer than the Low Income Taxpayer."3 In an attempt to quantify the distributional effects of tax expenditures, official reports of the Treasury and the Staff of the Joint Committee on Internal Revenue Taxation have produced tables which report the "Estimated Distribution of Selected Items of Tax Preferences of Individuals by Adjusted Gross Income Class." 4 These tables are used not only by the Treasury and the tax-writing committees of the Congress, but also by academicians analyzing the tax system, ${ }^{5}$ and they appear in casebooks designed to teach law students the fundamentals of income taxation. ${ }^{6}$ Ralph Nader's Tax Reform Research Group has argued that these estimated distributions of items of tax preference by income class understate the concentration of benefits in the higher income classes because of a failure to take into account the number of taxpayers in each income class. ${ }^{7}$

8 The Economics of Federal Subsidy Programs, hearings before the Subcomm. on Priorities \& Economy in Gov't. of the Jt. Econ. Comm., 92d Cong., 1st Sess. 48-59 (Jan. 1972) (statement of Stanley S. Surrey).

4 Tax Subsidies and Tax Reform, hearings before the Jt. Econ. Comm., 92d Cong., 2d Sess., app. E, at 165-68 (July 1972) [hereinafter cited as Tax Subsidies] (statement of Edwin S. Cohen, Under Secretary of the Treasury); Staff of Treasury Dep't. \& Jt. Comm. on Internal Revenue Taxation, Estimates of Federal Tax Expenditures, 92d Cong., 2d Sess., tab. 2, at 6-9 (Comm. Print, October 4, 1972) [hereinafter cited as Treasury \& Jt. Comm. Estimates], also reprinted in Prepared Statements Submitted to . . Panel Discussions on Tax Reform, before the House Comm. on Ways \& Means, 93d Cong., 1st Sess., pt. 1, at 31-34 [hereinafter cited as Panel Discussions].

5 Pathways 89-91.

6 Adrian A. Kragen \& John K. McNulty, Federal Income Taxation: Cases and Materials 644-645 (2d ed. 1974); Stanley S. Surrey, et at., Federal Income Taxation: Cases and Materials 43 (1973).

7 See Tax Subsidies 209-13 (statement of Thomas H. Stanton, Director, Tax Reform Research Group). An example of an estimate submitted by this group is set forth at 
Recent tax reform efforts, particularly the Tax Reform Act of 1969 and the Revenue Act of 1974 drafted by the House Ways and Means Committee, have taken the form of attempts to increase the "low effective rate of tax of high income taxpayers" by eliminating or reducing specific "tax expenditures" or "tax preferences." 8 Those who advocate elimination of tax preferences claim that it would increase the burden of taxation on high income taxpayers. Such conclusions flow naturally from the official estimates of the distribution of preferences by income class. But the estimates "do not take into account any effects that the removal of one or more of the items might have on investment patterns, consumption or other aspects of economic activity. In other words, the estimates shown do not take into account the induced effects of changing the provisions." The induced effects, however, can dramatically affect the distributional impact of elimination of a particular preference item. The question is closely related to the broader issue of tax incidence.

\section{Tax Shifting and Incidence, in General}

The incidence of a tax is determined by the changes it brings about in the distribution of real incomes available for private use. These changes depend principally upon the impact of the tax on relative prices and relative factor incomes. ${ }^{10} \mathrm{It}$ is axiomatic that the incidence of a tax can be quite different from what would be suggested merely by looking at the income groups subject to the statutory impact of the tax. A manufacturer's excise tax on automobiles, for

note 38 , infra. The overall impression of an inequitable distribution of tax benefits from tax expenditures has been bolstered by other estimates of the distribution of the tax burden by income class. See, e.g., The Economics of Federal Subsidy Programs, supra note 3, at 59-73 (statement of Joseph A. Pechman and Benjamin A. Okner). See also Joseph A. Pechman \& Benjamin A. Okner, Who Bears the Tax Burden? (Brookings, 1974).

8 See, e.g., Panel Discussions.

9 Treasury \& Jt. Comm. Estimates 2.

The Budget of the United States for Fiscal Year 1976 contains a special analysis of tax expenditures. This analysis acknowledges that the working hypothesis that "taxpayer behavior and general economic conditions [will] remain unchanged in response to the hypothetical change in the tax laws" is, in many cases, "unrealistic." Moreover, the analysis cautions against inferring

that the benefits of the special tax treatment rest fully or even mostly with the corporations or individuals whose taxes are initially affected. Benefits are often passed on to others in the form of lower prices for particular goods or services or in other ways become widely diffused. For example, the deductibility of charitable contributions does not merely lower individual or corporate liabilities; the individuals and institutions that receive the contributions benefit also.

Special Analyses, Budget of the United States Government, Fiscal Year 1976, Special Analysis F, Tax Expenditures, at 105, 107.

10 See Richard A. Musgrave \& Peggy Musgrave, Public Finance In Theory and Practice (1973) [hereinafter cited as Musgrave \& Musgrave]; Break 123; Joseph A. Pechman \& Benjamin A. Okner, supra note 7, at 27-29. 
example, while imposed by statute on and collected from automobile manufacturers can be expected to raise prices of automobiles relative to other goods and thus to be borne, at least in part, by purchasers of automobiles. To determine that such a tax is regressive, we must know that automobile consumption declines more rapidly as income rises than consumption of untaxed products. If consumption of automobiles declines less rapidly, the effect of the tax may be progressive. ${ }^{11}$

The most vigorous tax incidence dispute has been over the corporate income tax. ${ }^{12}$ Since it is imposed by statute on a legal entity, the corporation (which is nothing more than a collection of individuals organized within a particular legal framework to conduct business), the question naturally arises as to what classes of individuals are in fact burdened by the corporate income tax-shareholders, as owners of the firm? Employees of the firm? Consumers of the firm's products? Owners of capital generally? The question which class of individuals actually "pays" the tax is crucial in determining the distribution of the corporate tax burden by income class. ${ }^{13}$

Debates over tax incidence have not been limited to the corporate income tax. Until recently, economists generally agreed that the burden of the property tax on rental property was in large part shifted from owners of the property (the statutory taxpayers) to renters, who bore the tax in proportion to the rentals paid, ${ }^{14}$ and hence was regressive and should be replaced by "more progressive" (or "less regressive") forms of taxation, such as the value-added tax. ${ }^{15}$ But the traditional incidence assumptions concerning the property tax are undergoing intensive reexamination, and many economists

\footnotetext{
11 See Break 125-26; Musgrave \& Musgrave 429.
}

12 See, e.g., Marian Krzyzaniak \& Richard A. Musgrave, The Shifting of the Corporation Income Tax (1963); R. Goode, Rates of Return, Income Shares and Corporate Tax Incidence, and R. Slitor, Corporate Tax Incidence: Economic Adjustments to Differentials Under a Two-Tier Structure, both in The Facts of Corporate Income Tax (Marian Krzyzaniak ed. 1966); John G. Cragg, Arnold Harberger \& Peter Mieszkowski, Empirical Evidence of the Incidence of the Corporation Income Tax, $75 \mathrm{~J}$. Pol. Econ. 811 (1967); M. Krzyzaniak \& R. A. Musgrave, Corporation Tax Shifting: A Response, 78 J. Pol. Econ. 768 (1970); John G. Cragg, Arnold C. Harberger \& Peter Mieszkowski, Corporation Tax Shifting: Rejoinder, 78 J. Pol. Econ. 774 (1970); Break 138-54.

13 For example, one study has estimated that the effective tax rate of taxpayers with adjusted family income of one million dollars or more is $40 \%$ if the corporation income tax is assumed to be borne by shareholders but only $19 \%$ if borne by owners of capital generally, and an even lower rate if shifted forward to consumers. Joseph A. Pechman, Distribution of Federal and State Income Taxes by Income Classes, $27 \mathrm{~J}$. Fin. 179, 187 (1972) (tab. 4).

14 See, e.g., Henry Aaron, A New View of Property Tax Incidence, 64 Am. Econ. Rev. Papers \& Proceedings 212 (May 1974); Dick Netzer, Economics of the Property Tax (1966); Dick Netzer, The Incidence of the Property Tax Revisited, 26 Nat. Tax J. 515 (1973); Musgrave \& Musgrave 412-21; Break 154-68.

15 See, e.g., Frank V. Fowlkes, Administration Leans to Value-Added Tax to Help Solve National Fiscal Crises, 4 Nat. Tax J. 210 (1972). 
now view the property tax as a tax on capital with a decidedly progressive impact. ${ }^{16}$

Similarly, the incidence of payroll taxes has recently undergone careful scrutiny. General agreement has been reached that the burden of the employers' share of social security taxes is "shifted" to employees in the form of lower wages or to consumers in the form of higher prices. ${ }^{17}$ These conclusions have, of course, major implications with regard to the equity of financing any new government insurance scheme-for example, national health insurancethrough payroll taxes. ${ }^{18}$

As these comments suggest, assumptions about tax incidence play a key role in tax policy decisions. Indeed, incidence determinations are crucial to an evaluation of the degree of progressivity in the tax system as a whole. ${ }^{19}$ Yet the "true" incidence of the corporate income tax, the property tax, and the payroll tax has not been resolved. Economists perceive an urgent need for further research. ${ }^{20}$ Their present uncertainty has greatly complicated the formulation of tax policy. ${ }^{21}$

16 See Henry Aaron, supra note 14; Richard A. Musgrave, Is a Property Tax on Housing Regressive?, 64 Am. Econ. Rev. Papers \& Proceedings 222 (1974); Discussion by Brazer, Netzer, et al., 64 id. at 231-35.

17 See John A. Brittain, The Payroll Tax for Social Security (1972); John A. Brittain, The Incidence of Social Security Payroll Taxes, 61 Am. Econ. Rev. 110 (1971); Martin S. Feldstein \& John A. Brittain, The Incidence of the Social Security Tax: Comment and Reply, 62 Am. Econ. Rev. 735-42 (1972); Musgrave \& Musgrave 390-95; Break 168-75.

18 Both the Administration proposal and the Mills-Kennedy bill proposing a national health insurance plan would finance health insurance programs by payroll taxes.

10 The significance of various incidence assumption is illustrated by Professors Richard and Peggy Musgrave as follows:

20 See, e.g., Break; Joseph A. Pechman \& Benjamin A. Okner, supra note 7, at 10.

21 For example, Pechman and Okner, in a recent attempt to describe effective rates of tax, test five different assumptions about the incidence of the corporate, income tax. See Benjamin A. Okner \& Joseph A. Pechman, Who Paid the Taxes in 1966 ?, 64 Am. Econ. Rev. Papers \& Proceedings 168, 170 (tab. 1) (May 1974). Professors Richard and Peggy Musgrave adopt that "benchmark" assumption is that one-half of the corporate income tax is paid by consumers and one-half by recipients of income from capital. Musgrave \& Musgrave 367 (tab. 15-1). A special committee of the tax section of the American Bar Association evaluating a proposal for substitution of a value-added tax for the corporate income tax used two alternative assumptions about the burden of the corporate income tax. Report of a Subcomm. of the Spec. Comm. on Value Added Tax, Section of Taxation, American Bar Ass'n., Should the United States Adopt the ValueAdded Tax?, 26 Tax Lawyer 45, 51 (corporation income tax assumed to be borne twothirds by stockholders and one-third by consumers), 57 (corporation income tax divided equally between stockholders and consumers) (1972). The Treasury Department in testimony before the Joint Economic Committee of the Congress illustrated the distribution effects of five different assumptions. Tax Subsidies app. F, at 169 (statement of the Hon. Edwin S. Cohen, Undersecretary of the Treasury).

Pechman and Okner used three different assumptions about the burden of the property tax on improvements, and two assumptions about the incidence of the employer's share of the payroll tax. See Benjamin A. Okner \& Joseph A. Pechman, supra, at $170,169$. 
In contrast to the continuing uncertainty over the incidence of corporate income, property, and payroll taxes, economists consider the incidence of the individual income tax to be "relatively certain." 22 They have assumed it is not shifted at all but is borne by the statutory taxpayer. Every attempt to allocate the burden of income taxes by income class is based upon this assumption. ${ }^{23}$ This assumption also underlies the effective-tax-rate tables utilized by Treasury and congressional staff economists in providing information to decision makers

Significance of Altarnative Incidence Assumptions (Tax as Percent of Total Fammy Income)

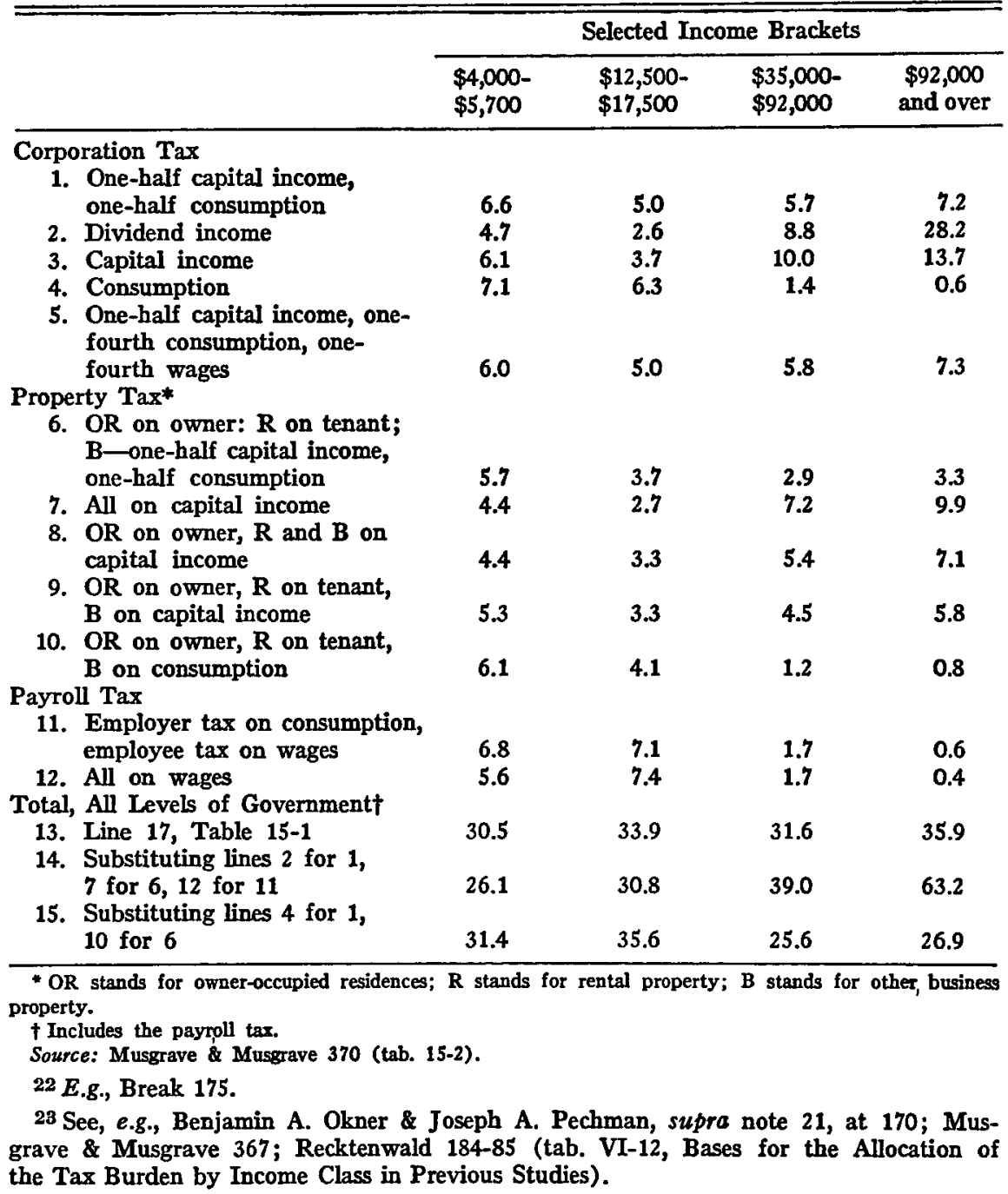


about the "burden distribution" by income classes of specific proposals for changing the tax law. ${ }^{24}$ Tables depicting the "estimated distribution of selected tax preferences" are also based upon this assumption.

But the universal application of the assumption is unwarranted. The implication of theoretical work in closely analogous areas is that selective shifting of the personal income tax does occur, and it could have dramatic impact in terms of the burden distribution of various tax changes by income class. By failing to consider this possibility, legislators may, as we are about to see, enact changes in the income tax laws that have distributional effects quite different from those desired.

\section{Excise-type Tax Effects of the Individual Income Tax AND of Income Tax SUbsmines}

The general assumption about the incidence of the individual income tax is based upon analysis of a "general" income tax..$^{25}$ But the income tax in the United States has never been such a tax. It involves a high degree of discrimination: income from different forms of capital produce varying tax liabilities; likewise, wage income in the form of fringe benefits or deferred compensation is often untaxed or taxed at reduced rates. In 1972 personal income in the United States totalled $\$ 936$ billion but taxable income amounted to only $\$ 446$ billion. And this pattern-where the tax base of the personal income tax is only about one-half of personal income--has been the prevailing condition in the United States for many years. ${ }^{26}$

Incidence assumptions based upon analyses of a "general" income tax are inadequate for policy recommendations for revising our nation's income tax laws because of the failure to take into account the nature and extent of the excise-tax-like changes in relative prices and factor incomes that are likely to be brought about as a result of the multiple discriminations in the personal income tax. Such changes will depend upon the operative tax provisions and the prevailing market forces. ${ }^{27}$ Income tax discrimination is so widespread

24 See note 4, supra. See also Joint Committee on Internal Revenue Taxation, General Explanation of the Tax Reform Act of 1969, 91st Cong., 2d Sess., at 17, tab. 5; Rep. of Comm. on Finance on the Tax Reform Act of 1969, Senate Rep. No. 91-552, 91st Cong., 1st Sess. 19 (tab. 5).

25 See, e.g., Musgrave \& Musgrave 378-390.

26 Compare U.S. Bureau of the Census, Statistical Abstract of the United States: 1973, at 324, with U.S. Dep't of the Treasury, Preliminary Statistics of Income-Individual Income Tax Returns: 1972 , at 5 (1974). Taxable income in 1972 was $47.6 \%$ of personal income. In 1968, personal income was $\$ 689$ billion; taxable income was $\$ 353$ billion$51.2 \%$ of personal income. See Otto Eckstein, Public Finance 60 (3d ed. 1974). In 1959, taxable income was $\$ 167$ billion while personal income totalled $\$ 383$ billion; taxable income was $43.6 \%$ of personal income. See Edwin S. Cohen, Substantive Federal Tax Reform, 50 Va. L. Rev. 628, 649-50 (1964).

27 See Richard Musgrave, Theory of Public Finance 370 (1959). 
that, given the current state of incidence-analysis methodology in a multiplediscrimination context, it may be more fruitful in developing policy recommendations to utilize micro-type analysis such as that employed in efforts to determine the distributional effects of excise taxes or subsidies. ${ }^{28}$

The suggestion that changes in relative prices and factor incomes are likely to result from income tax revision is consistent with an analysis of discriminatory income tax provisions as the equivalent of government expenditures, since, in incidence terms, subsidies are analogous to particular factor or excise-type taxes. ${ }^{29}$ Micro-analysis of the shifting and incidence of subsidies and welfare payments will often shed substantial light on the distributional effects of the subsidy. ${ }^{30}$

A recent "Tax Expenditure Budget" produced by the Joint Economic Committee of the Congress lists nearly $\$ 60$ billion of tax expenditures, ${ }^{31}$ but, as indicated earlier, estimates of the distribution of these "subsidies" by income class fail to take into account instances where the incidence of the subsidy is different from its statutory impact. When the recipient of the subsidy (in this case a reduced tax burden) loses all or part of the subsidy, the benefit is "shifted" ("shared" may be a better word for benefits) to others. ${ }^{32}$

In evaluating the distributional consequences of a repeal or revision of a "tax subsidy" provision, it is necessary to estimate what portion, if any, of the subsidy has been shared by the initial recipient with others and to determine the effect of this sharing on the relative income of the recipient and

28 Some economists have acknowledged that the discriminatory nature of the individual income tax in the United States suggests the possibility of some selective shifting:

The existence of various market imperfections may thus permit some shifting of the income tax. . . . However the extent of such shifting is likely to be selective rather than general. The overall conclusion remains that the individual income tax may by and large be taken to stay put.

Musgrave \& Musgrave 390. The tendency is to view this "as a matter of tax avoidance rather than shifting." Ibid. In part this seems to be due to the currently limited ability to make empirical estimates of tax incidence patterns in a multiple discrimination context. See Break 153. But there has been at least one attempt to quantify the incidence effects of differential taxation of income from capital. John B. Shoven \& John Whalley, A General Equilibrium Calculation of the Effects of Differential Taxation of Income from Capital in the U.S., 1 J. Pub. Econ. 281 (1972).

29 E.g., Carl Shoup, Public Finance 149-61 (1969).

30 Id. at 15-16.

31 Staff of the Jt. Econ. Comm., Federal Subsidy Programs (Comm. Print, October 17 1974), reprinted in BNA Daily Tax Rpt., Oct. 18, 1974, at J-1 to J-3. This estimate is similar in magnitude to other recent estimates. See, e.g., Pathways 7 ( $\$ 65$ billion estimate); Musgrave \& Musgrave 247 ( $\$ 55$ billion estimate). The most recent estimate of tax expenditures totals about $\$ 90$ billion. See Special Analyses, Budget of the United States Government, Fiscal Year 1976, at 108-09.

32 In many cases, the benefits of a subsidy will be divided between producer and consumer (buyer and seller), depending upon the relative elasticities of supply and demand. Carl Shoup, supra note 29, at 149-61. 
others. Since recent Congressional activity concerning "tax reform" has taken the form of attempts to increase the "low effective rate of tax of high income taxpayers" by eliminating or reducing specific "tax preferences," the distributional implications of such "shifting" will be illustrated in the context of tax preferences targeted for revision by those who seek a more progressive income $\operatorname{tax}$.

\section{A Clear Case of Some Shifting-Interest on TAX-Exempt Bonds}

The exemption from income tax of interest on state and local bonds ${ }^{33}$ is often described as one of the most important provisions allowing high-income taxpayers to escape tax and thus eroding the progressivity of the income tax. Although the issue has not been addressed explicitly as a question of incidence or shifting, it is clear that if the present tax exemption were eliminated the entire increase in tax would not be borne by the purchasers of taxable state and local bonds who would, as a statutory matter, pay the tax on the interest from the bonds. ${ }^{34}$ The tax exemption has lowered the amount of tax paid by owners of the bonds, but it has also lowered the interest paid by state and local governments to owners of such bonds. The benefits of the tax exemption are, in effect, shared by the owners of the bonds (the statutory beneficiaries) and state and local governments.

The effect of the tax exemption on interest rates of municipal bonds is in Table 1, which sets forth the ratio of yields of municipal bonds to yields

TABLE 1

Ratio of New Issue Municipal to Corporate Bonds Yields ${ }^{a}$

\begin{tabular}{lccccc}
\hline & \multicolumn{3}{c}{ Grade } & \\
\cline { 2 - 5 } Year & AAA & AA & A & BAA \\
\hline 1955 & 69 & 71 & 79 & 81 \\
1960 & 68 & 74 & 76 & 79 \\
1965 & 70 & 71 & 72 & 73 \\
1966 & 67 & 68 & 70 & 70 \\
1967 & 64 & 65 & 67 & 67 \\
1968 & 64 & 65 & 67 & 73 \\
1969 & 70 & 72 & 73 & 70 \\
1970 & 73 & 73 & 73 & 67 \\
1971 & 69 & 69 & 69 & 69 \\
1972 & 70 & 70 & 70 &
\end{tabular}

(Municipal yields/corporate yield) $\times 100$.

Source: Computed from Moody's.

33 Internal Revenue Code of 1954, \& 103.

34 See Joseph A. Pechman, Federal Tax Policy 99-101 (2d ed. 1971); David J. Ott \& Allan H. Meltzer, Federal Tax Treatment of State and Local Securities (1963).

35 See Panel Discussions, pt. 8, at 1211 (tab. 2) (statement of Wallace O. Sellers). 
of corporate bonds considered to be similar credit risks. The effect is also reflected in estimates of the distribution of the total revenue loss from the tax exemption among state and local governments and owners of the bonds. The House Ways and Means Committee estimated in 1969 that a total revenue loss to the federal government of $\$ 1.8$ billion produced a $\$ 1.3$ billion annual savings in interest costs for state and local governments. ${ }^{36} \mathrm{~A}$ more recent estimate suggests a total loss of $\$ 3.3$ billion with an interest savings to states and localities of $\$ 2.5$ billion. ${ }^{37}$ Using either of these estimates, the savings to state and local governments is about 70-75 per cent of the total revenue loss. Elimination of the tax exemption would undoubtedly require higher interest rates for state and local bonds. Yet the official "estimated distribution by adjusted gross income class" of the $\$ 1$ billion revenue loss due to individuals' taking advantage of the tax exemption does not take into account the interest savings. Table 2 reproduces the official estimates: ${ }^{38}$

Table 3 illustrates a distribution that reflects the savings in interest costs to state and local governments. The table is based on the assumption that state and local governments will finance the increased interest costs that would result from repeal of the tax exemption through general tax revenues. ${ }^{39}$

86 Report of the Committee on Ways and Means on the Tax Reform Act of 1969, pt. 1, at 173 (1969). For a discussion of the uncertain nature of estimates of the revenue loss from the tax exemption for state and local bonds, see Michael J. Graetz, Reflections on the Tax Legislative Process: Prelude to Reform, 58 Va. L. Rev. 1389, 1415-22 (1972).

37 Panel Discussions pt. 8, at 1235 (statement of Dr. Frank E. Morris).

38 See also Treasury \& Jt. Comm. Estimates 9. As indicated in the text at note 7, estimates by the Tax Reform Research Group which take into account the number of individuals in each adjusted gross income class show an even greater concentration of benefits in the higher income classes:

\begin{tabular}{cc}
\hline Adjusted gross income class & $\begin{array}{c}\text { Exemption of interest on state and local debt } \\
\text { (in dollars per return) }\end{array}$ \\
\hline $\begin{array}{r}0 \text { to } \$ 3,000 \\
\$ 3,000 \text { to } \$ 5,000\end{array}$ & 0.28 \\
$\$ 5,000$ to $\$ 7,000$ & $*$ \\
$\$ 7,000$ to $\$ 10,000$ & .39 \\
$\$ 10,000$ to $\$ 15,000$ & .71 \\
$\$ 15,000$ to $\$ 20,000$ & 3.61 \\
$\$ 20,000$ to $\$ 50,000$ & 27.81 \\
$\$ 50,000$ to $\$ 100,000$ & 853.00 \\
$\$ 100,000$ and over & $4,621.31$ \\
\hline
\end{tabular}

Source: Tax Subsidies 213 (statement of Thomas H. Stanton).

39 This table is based on the assumption that $70 \%$ of the revenue loss from the tax exemption is reflected in lower interest costs to state and local governments and that this $70 \%$ benefits income classes of individuals in proportion to the burdens that they bear of general state and local tax revenues. In other words, the table assumes that repeal of the exemption would increase interest costs to state and local governments and that state and local governments would finance the increased interest costs out of 
TABLE 2

Estmated Distribution of Selected Items of Tax Preference by Adjusted Gross Income Class, Calendar Year 1972

\begin{tabular}{ccc}
\hline Adjusted gross income class & $\begin{array}{c}\text { Exemption of interest on state and local debt } \\
\text { (in millions of dollars) }\end{array}$ \\
\hline 0 to $\$ 3,000$ & 5 \\
$\$ 3,000$ to $\$ 5,000$ & - \\
$\$ 5,000$ to $\$ 7,000$ & 5 \\
$\$ 7,000$ to $\$ 10,000$ & 10 \\
$\$ 10,000$ to $\$ 15,000$ & 25 \\
$\$ 15,000$ to $\$ 20,000$ & 125 \\
$\$ 20,000$ to $\$ 50,000$ & 375 \\
$\$ 50,000$ to $\$ 100,000$ & 455 \\
$\$ 100,000$ and over & 1,000 \\
Total &
\end{tabular}

Source: Pathways 91.

TABLE 3

\begin{tabular}{cc}
\hline Adjusted gross income class & $\begin{array}{c}\text { Exemption of interest on state and local debt } \\
\text { (in millions of dollars) }\end{array}$ \\
\hline $\begin{array}{c}0 \text { to } \$ 3,000 \\
\$ 3,000 \text { to } \$ 5,000\end{array}$ & 56.5 \\
$\$ 5,000$ to $\$ 7,000$ & 77 \\
$\$ 7,000$ to $\$ 10,000$ & 91 \\
$\$ 10,000$ to $\$ 15,000$ & 99.5 \\
$\$ 15,000$ to $\$ 20,000$ & 130 \\
$\$ 20,000$ to $\$ 50,000$ & 40.5 \\
$\$ 50,000$ to $\$ 100,000$ & 72.5 \\
$\$ 100,000$ and over & 141.5 \\
\hline
\end{tabular}

The official estimates, which ignore the interest savings to state and local governments, show that 83 per cent of the benefits from the tax exemption

general revenues. Of course, the impact of repeal of the exemption would vary from state to state but no attempt has been made to take interstate differences into account. The allocation of the burden of general state and local taxes is derived from Table 3 of a paper by Atliat F. Ott, Estimating the Distribution of the Tax Burden (U.S. Treasury Dep't, Office of the Secretary, Office of Tax Analysis). Ott derived her distribution of state and local taxes from the following incidence assumptions:

(1) Individual income taxes are borne by the statutory taxpayer.

(2) Corporate income taxes are borne by the owners (zero shifting).

(3) Excise and sales taxes are shifted forward to consumers.

(4) Estate and gift taxes are not shifted.

(5) Payroll taxes fall on wage earners.

(6) Property taxes are borne equally by homeowners (and renters) and consumers.

Other incidence assumptions would produce different results, but the general direction of change between Table 2 and Table 3 would be the same. Table 3 allocates the 30\% of the benefit of the tax savings (which is not reflected in lower interest costs) by income class in the same manner as Table 2 allocates the entire benefit. 
accrues to individuals with adjusted gross income over $\$ 50,000$ and only four per cent of the benefits goes to individuals with adjusted gross income of $\$ 20,000$ or less. But when the interest savings is taken into account, the benefits from the tax exemption appear to be spread far more evenly through the income classes. About half of the benefits goes to individuals with adjusted gross incomes of $\$ 20,000$ or less, and less than one-third of the revenue loss benefits individuals with adjusted gross incomes above $\$ 50,000$. Repeal of the tax exemption would have dramatically different effect on the progressivity of the income tax from that suggested by the official estimates.

A general recognition that the distribution of benefits from the tax exemption is more closely approximated by the second table than by the first may partially explain the recent coupling of proposals for elimination of the exemption with suggestions for a new federal payment to state and local governments to subsidize interest on taxable bonds. ${ }^{40}$

\section{Tax Shelters for Low- and Moderate-Income Housing}

The Internal Revenue Code contains a variety of provisions reducing income taxes on investors in low and moderate income housing. The use of these provisions in combination produces one common variety of the real estate tax shelter. ${ }^{41}$ The most notable of these provisions are those allowing accelerated depreciation on the full cost of housing including borrowed funds; ${ }^{42}$ a five-year write-off for expenses for major rehabilitation of low and moderate income housing; $;^{43}$ deduction of interest and taxes during the construction period; ${ }^{44}$ and a rollover provision which permits deferral of tax on any gain from the

\footnotetext{
40 See, e.g., Panel Discussions, pt. 8; Report of the Committee on Ways \& Means, supra note 36 , at 172 . There may be good policy reasons for eliminating the tax exemption for interest on state and local bonds, particularly if such elimination is accompanied by a direct interest subsidy. For example, there would likely be gains in efficiency: new markets such as pension funds where the tax exemption now provides no inducement would be opened for state and local bonds. But the increase in progressivity that would result from such a change is often overstated because of a failure to take into account changes in interest rates that would occur if the tax exemption were eliminated.

41 For a detailed description of the low-income housing tax shelter see Panel Discussions, pt. 4, at 559-72 (statement of Jerome Kurtz); Jerome Kurtz, Real Estate Tax ShelterA Postscript, 26 Nat. Tax J. 341 (1973); William S. McKee, The Real Estate Tax Shelter: A Computerized Exposé, 57 Va. L. Rev. 521 (1971); C. Willis Ritter \& Emil M. Sunley, Jr., Real Estate and Tax Reform: An Evaluation of the Real Estate Provisions of the Tax Reform Act of 1969, 30 Md. L. Rev. 5 (1970).

42 See Crane v. Comm'r, 331 U.S. 1 (1947); Parker v. Delaney, 186 F.2d 455 (1st Cir. 1950), cert. denied 341 U.S. 926 (1951). See also Internal Revenue Code of 1954 $\S 167(\mathrm{j})$.

43 Internal Revenue Code of 1954, § $167(\mathrm{k})$.

44 Internal Revenue Code of $1954, \$ 8163 \& 164$.
} 
sale of such housing ${ }^{45}$ until death, when income tax on the gain is forgiven forever. ${ }^{46}$

Proponents of elimination of the tax benefits for low- and moderate-income housing have indicated that the major benefits of the tax reductions accrue to high income taxpayers, and that the provisions therefore undermine the progressivity of the tax system. ${ }^{47}$ For example, the Treasury and Joint Committee on Internal Revenue Taxation ${ }^{48}$ estimate the distribution of the tax benefits of accelerated depreciation and rehabilitation write-off by income class as follows:

TABLE 4

Estrmated Distribution of Selected Items of Tax Preferences of Individuats by Adjusted Gross Income Class, Calendar Year 1972

\begin{tabular}{|c|c|c|}
\hline $\begin{array}{l}\text { Adjusted gross } \\
\text { income class }\end{array}$ & $\begin{array}{l}\text { Depreciation } \\
\text { on rental } \\
\text { housing in } \\
\text { excess of } \\
\text { straight-line }\end{array}$ & $\begin{array}{c}\text { Housing } \\
\text { rehabilitation }\end{array}$ \\
\hline 0 to $\$ 3,000$ & $1,000,000$ & a \\
\hline$\$ 3,000$ to $\$ 5,000$ & $4,000,000$ & $\mathbf{a}$ \\
\hline$\$ 5,000$ to $\$ 7,000$ & $7,000,000$ & a \\
\hline$\$ 7,000$ to $\$ 10,000$ & $14,000,000$ & $\mathbf{a}$ \\
\hline$\$ 10,000$ to $\$ 15,000$ & $28,000,000$ & $\$ 1,000,000$ \\
\hline$\$ 15,000$ to $\$ 20,000$ & $25,000,000$ & $1,000,000$ \\
\hline$\$ 20,000$ to $\$ 50,000$ & $86,000,000$ & $3,000,000$ \\
\hline$\$ 50,000$ to $\$ 100,000$ & $53,000,000$ & $8,000,000$ \\
\hline$\$ 100,000$ and over & $32,000,000$ & $12,000,000$ \\
\hline Total & $\$ 250,000,000$ & $\$ 25,000,000$ \\
\hline
\end{tabular}

a Less than $\$ 500,000$.

Table 4 shows that 70.5 per cent of the tax savings is distributed to individuals with more than $\$ 20,000$ of income. Individuals with adjusted gross incomes between $\$ 7,000$ and $\$ 20,000$ receive about 25 per cent of the benefits, and individuals with adjusted gross incomes of $\$ 7,000$ or less-low income individuals-receive less than five per cent of the benefits.

But this distribution assumes that individuals who pay lower taxes because of these provisions receive the entire benefits of the tax reduction. However,

45 Internal Revenue Code of 1954, \& 1039.

46 Internal Revenue Code of 1954, $\$ 1014$.

47 See, e.g., materials cited supra note 41; Pathways 236-46. Professor Surrey focuses his major criticism on the inefficiency of using the tax system as a means of subsidizing low and moderate income housing. This criticism and an overall evaluation of the provisions are beyond the scope of this article.

48 Pathways 89. See also Treasury \& Jt. Comm. Estimates 7. 
the tax reductions for investments in low and moderate income housing may be at least partially reflected in lower rents for low and moderate income housing. ${ }^{49}$ The debate over the incidence of the local real property tax is relevant here. Many studies of the property tax assume that owners of rental property shift the tax on improvements to renters by charging higher rents. ${ }^{50}$ This view has been challenged recently and some argue that the property tax is borne by owners of capital. ${ }^{51}$ But no comparable debate has occurred over possible shifting of the income tax on rental income. If the value of property merely represents the current discounted value of a future stream of income, why should the incidence of a property tax on value differ substantially from that of an income tax on rents from the property ${ }^{52}$ No attempt has been made to delineate the characteristics of an income tax that would produce different incidence results. ${ }^{53}$

Professor Musgrave has provided an analysis of a national property tax on housing in which he expresses particular concern about the incidence of such a tax on rents for low and moderate income housing:

... While comprising only 20 per cent of the total housing base, rental housing is of special concern since it weighs heavily at the lower end of the income scale. Housing markets, especially for low-income housing in central city settings, may well be markets where landlords act as restrained monopolists (being threatened by rent control and/or public rage) who find it justified to raise rents as taxes are increased, or where tax increases may act as a signal to landlord-oligopolists to raise rents. Rate reductions in turn may or may not have opposite effects. While the fact that rental contracts or rent controls frequently allow for tax increases

49 The possibility that special tax provisions for investments in real estate produce lower rents was acknowledged by Jerome Kurtz, former Tax Legislative Counsel of the United States Treasury Department, in testimony before the Ways and Means Committee where he stated: "Real estate is a risky industry. The question is whether the developer ought to be compensated for undertaking these risks by the Federal Government through the tax system. Developing a shopping center takes six, seven, eight years, which is not at all unusual but why should Macy's pay less rent because the Federal Government is granting tax incentives to the developer to build it." Panel Discussions, pt. 4, at 578. Henry Aaron in an extensive study of housing subsidies attempted to quantify the reduction in rental housing costs as a result of the favorable accelerated depreciation provisions. See Henry Aaron, Shelter and Subsidies: Who Benefits from Federal Housing Policies? 66-69 (Brookings 1972).

${ }^{5} 0$ See, e.g., Dick Netzer, Economics of the Property Tax, supra note 14; Musgrave \& Musgrave 412-21.

51 See, e.g., Henry Aaron, supra note 14, at 212; Peter Mieszkowski, The Property Tax: An Excise Tax or a Profits Tax?, 1 J. Pub. Econ. 73 (1972); Dick Netzer, The Incidence of the Property Tax Revisited, supra note 14.

52 The question in the text ignores geographical disparities due to the fact that the property tax in the United States is imposed at a local level. The better property tax analogue for the question raised in the text would be a national property tax. See Richard A. Musgrave, supra note 16.

53 See Boris I. Bittker, supra note 11 , at 799, n. 50. 
is no proof that the tax is passed on to consumers through the mechanism of imperfect markets, it at least raises such suspicion. Given inelastic demand for low cost housing and a relatively elastic short-run supply through varying levels of maintenance, these possibilities cannot be ruled out. I would suspect that a substantial amount of initial shifting into higher rentals does in fact result. This being the case, I do not accept the extreme assumption that no part of the tax is shifted to the tenants. Rather, I prefer to allocate a substantial part of the tax on this basis. ... The burden-shifting now visualized involves an initial passing on of the burden from landlords (on whom the statutory burden rests) to tenants. Landlords effect this by drawing on previously unrealized monopoly power, thus leaving capital income initially free of burden (or in any case with a lesser burden) and involving a burdening of tenants rather than a redistribution among consumers. While further shifts in capital allocation and excise effects will follow, the end result will differ (i.e., leave a heavier burden on tenants and be more regressive) from that under [another] model. ${ }^{54}$

Professor Musgrave's description of the market for low and moderate income housing suggests that similar shifting assumptions might also be appropriate for increases in the income tax on landlords' rental income from low and moderate income housing.

The profit-maximization assumption is clearly not valid when applied in the context of housing programs where the government has limited before-tax profits. For example, under section 236 of the National Housing Act, mortgage funding is provided but the investor is limited to a return of six per cent before tax on the amount invested above the mortgage. ${ }^{55}$ This produces about a four per cent return on the actual investment. ${ }^{56}$ This return is clearly inadequate to induce investment in a high-risk venture such as construction of low- and moderate-income housing. The entire section 236 program is premised on the fact that the current tax laws produce a much higher after-tax rate of return than the limited before-tax return implies. ${ }^{57}$ If the tax laws were changed to tax fully the nominal before-tax return, the six per cent allowable return would probably have to be at least tripled before any investment could be expected. Such an increase in the permitted rate of return would necessarily require higher rentals from the low and moderate income individuals who occupy such housing. Thus, an elimination of tax provisions that reduce income

54 Richard A. Musgrave, supra note 16, at 224. Professor Musgrave's view was questioned in the discussion that followed the presentation of Professor Musgrave's paper. See, e.g., 64 Am. Econ. Rev. Papers \& Proceedings 234 (May 1974) (statement of Earl R. Rolph).

65 National Housing Act of 1934, \& 236, 12 U.S.C. $\$ \$ 1701$ et seq. (1970). See Pathways 239-46; Panel Discussions, pt. 4, at 553-72 (statement of Jerome Kurtz). Many states that provide subsidies to low- and moderate-income housing also limit profits.

56 See Pathways 241.

67 For a taxpayer in the $50 \%$ marginal bracket, the after-tax return is in the neighborhood of 15-20\%. See Pathways 240. See also materials cited in note 41 supra. 
taxes on rents from low and moderate income housing is likely to be reflected partially in higher rentals, thereby producing a burden distribution quite different from that suggested by the official estimates. ${ }^{58}$

\section{Tax Shelters for Doctors-The Shifting Question From a Different ANGLE}

This part of the article approaches the shifting question in a different way. Rather than focusing on the price effect of specific tax preferences, I here discuss other possible sharing effects of tax reductions utilized by particular classes of taxpayers.

Doctors are notorious for their efforts to minimize income taxes by taxshelter investments. ${ }^{59}$ Since doctors typically earn high incomes, their use of tax-preference provisions is attacked as an erosion of the progressivity of the income tax..$^{60}$ But one should ask whether the tax increases that would result if the preferences were eliminated could be shifted, in whole or in part, by the statutory taxpayers to others.

If individuals maximize monetary profits prior to imposition of the income tax-or prior to an increase in the tax-they will not be able to shift a tax increase to others by demanding higher payments. But if, prior to an increase in tax, they receive less than the maximum they are able to obtain, they might well succumb to pressures to maintain their after-tax income by increasing the prices charged for their services.

Doctors, in large part because of legal barriers to entry, may have discretion to set prices without regard to competition, and charity motives may sometimes produce zero prices or prices below marginal costs for poor patients. ${ }^{61}$ It may be that a tax increase would change their consumption mix, particularly their consumption of such in-kind charity, and would tend to inspire physicians to revise their fees upwards to maintain their previous after-tax position. Moreover, if they are already following a profit-maximization pricing policy

\footnotetext{
68 With respect to a closely analogous situation, the Congress, in the Tax Reduction Act of 1975 , P.L. 94-12, for the first time, attempted to deal with the possible price effects of a tax expenditure. A new tax credit of up to $\$ 2,000$ is provided for taxpayers who purchase a new principal residence in 1975 or 1976 . Internal Revenue Code of $1954, \S 44$. In an attempt to insure that the purchaser actually receives the benefits of the tax subsidy, the provision requires that the seller certify that the purchase price is the lowest price at which the residence was ever offered for sale. This provision does not, however, prevent the seller from capturing benefits of the tax subsidy where, but for the tax subsidy, a further price reduction would have been necessary in order to sell the property.

69 See, e.g., Panel Discussions, pt. 6, at 700 (statement of Paul R. McDaniel).

60 See, e.g., Pathways 134-38.

61 See Robert T. Masson \& S. Wu, Price Discrimination for Physician's Services, 9 J. Human Res. 63, 78 (1974); Roy J. Ruffin \& Duane E. Leigh, Charity, Competition, and the Pricing of Doctors' Services, 8 J. Human Res. 212 (1973).
} 
with regard to their high-income patients, as some of the literature suggests, ${ }^{62}$ then any price increase will necessarily fall on lower-income patients. If this description approximates reality, tax increases on doctors resulting from the elimination of tax shelters might be passed on, at least in part, to low-income consumers of medical services in the form of higher prices. ${ }^{63}$

Doctors have been chosen as the subject of this discussion because their monopolistic position is rather clear and because there is some evidence of their nonprofit-maximizing pricing policies. Similar compensation patterns may exist for lawyers, other professionals, and business executives operating in oligopolistic markets. ${ }^{64}$ A similar analysis may apply to certain labor unions; where unions have oligopolistic power, the possibility of some income tax shifting should not be ignored. If unions bargain with their employers in terms of after-tax wages, tax increases may stimulate wage increases which in turn might be passed on to consumers. ${ }^{65}$ There is some evidence that this has occurred in other countries. ${ }^{66}$

If the profit-maximization assumption is of only limited validity, the nonshifting assumption should be similarly limited. As Professor Musgrave has stated in a different context:

[The decisive difference in shifting conclusions is] between models that do and others that do not require profit-maximizing behavior and perfect capital mobility. A theory which allows for imperfections and unconventional firm behavior, I insist, can be the first move in a general equilibrium analysis no less than one which rules them out. The outcome of the model depends on its behavioral assumptions,

62 Ibid.

63 Because of other government policies, however, the lower-income patient might not bear the total burden of any increased price of medical services. The existence of Medicare and Medicaid programs and widely used health insurance further complicates the incidence question.

64 See Musgrave \& Musgrave 387-88; Break 179. Principally as a result of availability of more advantageous pension benefits for corporate employees, many doctors and lawyers have incorporated their medical and legal practices, which had previously been operated as proprietorships and partnerships. By setting appropriate salary levels for employees these professional corporations are typically able to reduce their corporate income tax liability to zero. If a corporate income tax were paid, the question whether the tax would be borne by the doctors or lawyers as owners of the corporation or by their patients as consumers of the corporation's services or by owners of capital would be vigorously debated as part of the general issue of the incidence of the corporate income tax. But if the possibility of shifting is so widely recognized when the income tax is imposed at the corporate level, why is it so universally ignored when the income tax is imposed directly on the individual? The difference in legal organizations alone cannot explain this divergent treatment. If a corporate income tax can be shifted to consumers, surely it would be possible for similar shifting to take place when an income $\operatorname{tax}$ is imposed on unincorporated enterprises.

65 See Break 178. The impact of such a possibility on absolute prices would also upset many commonly held notions about the effect of tax changes on rates of inflation.

66 See Break 178, n. 127. 
including those which determine the initial response to the tax. It is, after all, but a dispensing machine, where the juice you draw depends on which button you push. While model builders like to assume away imperfections and market behavior not aimed at profit maximization, it does not follow that no such things exist. It just means that the economist's job is more difficult and that an understanding of institutions becomes more important. ${ }^{67}$

Again, the possibility of shifting suggests distributional consequences of tax changes quite different from those commonly assumed by decision-makers.

\section{Conclusion}

A consensus exists in the economic literature that the individual income tax is not shifted but is borne at the point of legal impact. The purpose of this article has been to raise questions about the validity and universality of this assumption. The nonshifting assumption is typically formulated in the context of a general tax on income applied uniformly to all forms of economic income. The income tax in the United States is very different from this economic model. Given the numerous discriminations in tax, changes in relative prices and factor incomes seem likely. In addition, the nonshifting hypothesis is firmly predicated on the profit-maximization assumption-the assumption that individuals have maximized their monetary income prior to imposition of any income tax. It may be that individuals, particularly professionals, other highincome individuals in oligopolistic markets, and certain labor unions do not set prices to maximize before-tax profits.

The nonshifting assumption has not only been utilized in estimating the general distribution of the income tax but also in estimating the distribution of benefits of "tax subsidies" among various income classes. But there is a need to apply incidence analysis to determine the effects of particular tax subsidies on the relative distribution of income. Allocation of all of the benefits of tax subsidies to the statutory beneficiaries will distort the real impact of the tax change under consideration. I have demonstrated that changes in particular provisions of the individual income tax seem likely to have significant price effects and that the possibility of substantial selective shifting exists. An awareness of the potential significance of this phenomenon should move the investigation of individual income tax incidence and the incidence of income tax subsidies to a higher priority in the agenda of scholars and policymakers.

67 Richard Musgrave, supra note 16, at 244-45. 